\title{
The Implications of Information and Communication Technology on Tax Administration in the Growth and Development of Nigeria's Economy
}

\author{
Onwubuya, Sunday Kelvin \\ Federal College of Education (Technical), \\ Asaba, Delta State \\ Computer Education Department \\ E-mail Address: evansko2003@yahoo.com \\ Phone Number: 08063600338
}

\author{
Prof. Inyiama H.C. \\ Ebonyi State University Abakiliki \\ Faculty of Sciences, \\ Department of Computer Science \\ Phone Number: 08034701121, 09078847530
}

\begin{abstract}
This paper focuses on the implications of Information and Communication Technology on Tax administration in the growth and development of Nigeria's economy. Three research questions and three hypothesis guided the study. The study was a descriptive survey design with a population of 180 respondents randomly sampled and selected among the staff of Federal Board of Internal Revenue and State Board of Internal Revenue in Delta State. A six point likert type of questionnaire was developed, validated and administered to the respondents through simple random sampling technique. The responses gathered were coded and analyzed using independent t-test statistics for data analysis. Three null hypothesis were formulated and tested at critical t-test value of 1.96 at 0.05 level of significance. Based on the findings that resulted from this study, it was concluded that the availabilities of ICT tools/facilities, the use of Information and Communication Technology, and the presence of ICT tax administrators will lead to better, effective and efficient running of the day-to-day tax related activities, filing of tax returns, tax processing and computations of tax payment liabilities. It was also recommended that Government should equip the nation's tax offices and agencies with adequate ICT tools and facilities and also seminars and workshops should occasionally be organized to acquaint tax administrators and the relevant tax agencies on the practical use and applications of ICT tools and facilities in enhancing tax compliance.
\end{abstract}

Keywords: ICT, tax, tax administrators, tax agencies, development, growth

$* * * * *$

\section{Introduction}

Taxation is the main source of money for government spending. Taxes include a diverse collection of ways in which the government raises money. Therefore, taxation is the main way the government raises revenue from individuals and businesses (Mandel, 2012). This is in line with Samuelson and Nordhaus (2010), which opined that in taxing, government is actually deciding how best to draw the required resources from the nation's households and businesses for public purposes. They further stated that the money raised through taxation is the vehicle by which real resources are transferred from private goods to collective goods

According to Okonta, et al (2013), Information and Communication Technology (ICT) is seen as the science and skills of all aspects of computing, data storage, and communication. It is a new rapidly growing area that is radically changing the world by making possible new ways of doing business, making entertainment, creating art and teaching and learning. The current emphasis on the use of technology within businesses is not a mirage. Indeed, all indicators point to the increased use of technology and to organizations continued awareness of the importance of technology, both as a tool for productivity and as a vehicle for achieving competitive advantage and organizational change. People in organizations use information systems to process sales transactions, manage loan applications, or help financial analysts decide where, when, and how to market their products and related services, and production managers use them to help decide when and how to manufacture products (Joe and Christoph, 2010). They further propounded that data and knowledge are probably among the most important assets an organization has, as data and knowledge are essential for both executing business processes and gaining business intelligence. Databases, which are collections of related data organized in a way that facilitates data searches, are vital to an organizations success. Information once taken for granted or never collected at all is now used to make organizations more productive and competitive. Stock prices in the market, potential customers who meet a company's criteria for its products target audiences and the credit rating of wholesalers and customers are all types of information that organizations collect and analyze.

For effective, efficient and reliable tax administration, a tax system has to observe the fundamental principles of taxation which are equity, simplicity, economy, and certainty. In order to discharge its duties to the people it governs, a good government in power has to put in place a good system of taxation. The distribution of the tax burden has to be ascertained in respect of who will pay taxes, how much they will pay and how the taxes collected will be spent. Tax 
imposed may be progressive, regressive or proportional (Oseni, 2016). Therefore, this paper tends to investigate the implications of ICT on tax administration in the growth and development of Nigeria's economy.

\section{Statement of the Problem}

A tax is a compulsory exaction of money by a public authority for public purposes, while the process of levying and collection of taxes from taxable persons is known as taxation (Lekan and Sunday, 2006). Taxes include personal income tax, company tax and value added tax among others (Mandel, 2012). The taxation of income has often created controversy. Many people oppose their government taking portions of their earnings to fund programs they may not support. Politicians and economists have also long debated how to design fair and simple income tax systems. Based on the foregoing therefore, the following has been identified as possible problems which the study tends to address.

- Unskilled tax employee/agent who lacks the basic knowledge of ICT.

- Wrong filings of tax returns by tax payers.

- Wrong computation and processing of taxes by various tax agents (manual method of computation).

- Papers, files and file cabinets are bulky and occupy very large spaces.

- Lack of distributed databases for accessing tax information at various tax revenue collecting and processing offices.

- Consequent losses of tax revenues to the government through the incidence of tax evasion and tax dodge.

- Discrepancies in the amount of tax paid by individuals and various companies in the area of personal income tax, company tax and value added tax.

\section{Objectives of the Study}

The main objective of the study was to investigate the implications of ICT on tax administration in the growth and development of Nigeria's economy. Specifically, the study is aimed at determining:

1. The availability of ICT tools and facilities for the processing and computation of tax liabilities.

2. The extent of the integration and implementation of ICT tools in the Federal Inland Revenue Service for effective and efficient tax processing and computation.

3. The degree of the presence of ICT tax administrators as the main motivators and initiators of the ICT implementation at the Federal Inland Revenue Board to enhance tax administrative processes.

\section{Research Questions}

The following research questions guided the study.

1. Does the availability of ICT tools and facilities enhance the processing and computation of tax liabilities?

2. What impact does the use of Information and Communication Technology have on the final computation and processing of tax liabilities?

3. To what extent has the presence of ICT to tax administrators affected tax administrative processes?

\section{Research Hypothesis}

HO1: There is no significant difference on the availability of ICT tools/facilities for the processing and computation of tax liabilities.

HO2: There is no significant impact on the use of information and communication technology in filing tax returns, computing, processing, and assessing tax related information.

HO3: There is no significant impact on the presence of tax administrators having knowledge in ICT on the overall tax administrative processes by tax administrators and various tax agencies in the country.

\section{Research Design and Population}

The research design adopted for this study was the survey descriptive study. The study area was Delta State of Nigeria. The study population comprises of Delta State Board of Internal Revenue and Federal Board of Internal Revenue currently in operation in Delta State. The sample consists of 180 staff (male and female) randomly selected through the simple random sampling technique from both Boards.

\section{Validation and Instrumentation}

The research questions were reviewed for face and content validities by experienced personnel's in the field of computer and tax administration. A test-retest method was adopted in testing the reliability of the instrument.

\section{Data Analysis}

The data analysis and results were presented with special reference to the research hypothesis in the study. Each hypothesis was tested using the responses from respondents to the questionnaire questions which relates to and explain the various null hypotheses and the t-test statistical analysis.

\section{Results}

Hypothesis 1 (One)

HO1: There is no significant difference on the availability of ICT tools/facilities for the processing and computation of tax liabilities. 
Table 1: Summary Table of calculated t-test analysis for hypothesis 1.

\begin{tabular}{|c|c|c|c|c|c|c|c|}
\hline Availability of ICT tools/facilities & $\mathrm{N}$ & mean & SD & Df & t-calculated & t-critical & Decision \\
\hline Available & 104 & 10.12 & 4.35 & 178 & 5.01 & 1.96 & Significance \\
\hline Not Available & 76 & 5.21 & 1.56 & & & & $\begin{array}{c}\text { No } \\
\text { Significance }\end{array}$ \\
\hline
\end{tabular}

$\mathrm{p}>0.05, \mathrm{df}=178, \mathrm{t}$-critical $=1.96, \mathrm{t}$-calculated $=5.01$

From table 1 above, it was observed that the t-calculated value of 5.01 is greater than the t-critical value of 1.96, at 0.05 level of significance. This implies that the null hypothesis one stated above is rejected as postulated and the alternative hypothesis is accepted. Therefore, the conclusion reached was that there is a significance difference on the availability of ICT tools/facilities in the processing and computation of tax liabilities of tax payers.

\section{Hypothesis 2 (Two)}

HO2: There is no significant impact on the use of information and communication technology in filing tax returns, computing, processing, storing, and assessing tax related information.

Table 2: Summary Table of calculated t-test analysis for hypothesis 2.

\begin{tabular}{|c|c|c|c|c|c|c|c|}
\hline Use of ICT in filing tax returns & $\mathrm{N}$ & mean & $\mathrm{SD}$ & $\mathrm{Df}$ & $\mathrm{t}$-calculated & $\mathrm{t}$-critical & Decision \\
\hline Adequately Used & 125 & 8.52 & 4.79 & 178 & 4.13 & 1.96 & Significance \\
\hline Not Adequately Used & 55 & 3.31 & 1.01 & & & & $\begin{array}{c}\text { No } \\
\text { Significance }\end{array}$ \\
\hline
\end{tabular}

$\mathrm{p}>0.05, \mathrm{df}=178, \mathrm{t}$-critical $=1.96, \mathrm{t}$-calculated $=4.13$

From table 2 above, it was observed that the t-calculated value of 4.13 is greater than the t-critical value of 1.96 , at 0.05 level of significance. This means that the null hypothesis two stated above is rejected as postulated and the alternative hypothesis is accepted. Therefore, the conclusion reached was that there is a significance difference on the use of information and communication technology in filing tax returns, computing, processing, storing, and assessing tax related information.

\section{Hypothesis 3 (Three)}

HO3: There is no significant impact on the presence of tax administrators having knowledge in ICT in the overall tax administrative processes by tax administrators and various tax agencies in the country.

Table 3: Summary Table of calculated t-test analysis for hypothesis 3.

\begin{tabular}{|c|c|c|c|c|c|c|c|}
\hline Use of ICT in filing tax returns & $\mathrm{N}$ & mean & $\mathrm{SD}$ & $\mathrm{Df}$ & $\mathrm{t}$-calculated & $\mathrm{t}$-critical & Decision \\
\hline Adequately Used & 106 & 6.20 & 4.64 & 178 & 4.02 & 1.96 & Significance \\
\hline Not Adequately Used & 74 & 2.53 & 1.22 & & & & $\begin{array}{c}\text { No } \\
\text { Significance }\end{array}$ \\
\hline
\end{tabular}

$\mathrm{p}>0.05, \mathrm{df}=178, \mathrm{t}$-critical $=1.96, \mathrm{t}$-calculated $=4.02$

From table 2 above, it was observed that the t-calculated value of 4.02 is greater than the t-critical value of 1.96 , at 0.05 level of significance. This means that the null hypothesis three stated above is rejected as postulated and the alternative hypothesis is accepted. Therefore, the conclusion reached was that there is a significance difference on the presence of tax administrators having knowledge in ICT in the overall tax administrative processes by tax administrators and various tax agencies in the country.

\section{Discussions of Findings}

From table one above, in testing hypothesis 1; it was observed that there is a significant difference on the availability of ICT tools/facilities in the processing and computation of tax liabilities of tax payers. Also, testing hypothesis two as noted from the above table two, it was equally concluded that there is a tremendous significant difference on the use of Information and Communication Technology in filing tax returns, computing, processing, storing, and assessing tax related information. These observations are in agreement with Odogbo (2002), which stated that computers can handles jobs a million times faster than human beings. Computers can process large volume of calculations in less than half a seconds. $\mathrm{He}$ is also of the 
view that sorting, preparing and filing of documents and retrieving of information are done faster when we employ the use of computers.

Finally, in testing hypothesis three from the above table three, it was also observed that there is a significance difference on the presence of tax administrators having knowledge in ICT in the overall tax administrative processes by tax administrators and various tax agencies in the country. This also is in line with Obot (2009), which is of the opinion that with the presence of ICT, the way businesses are done has changed, the way classes are attended to in schools, the way information is disseminated and the way business products are bought and sold have all changed tremendously. This implies that training and retraining of staff on the effective use of ICT tools enhances and leads to better administrative performance.

\section{Conclusions}

Based on the findings that resulted from this study, it was concluded that the availabilities of ICT tools/facilities, the use of Information and Communication Technology, and the presence of ICT tax administrators, when fully employed in the nation's tax industries will lead to a better, effective and efficient running of the day-to-day tax related activities, firing of tax returns, tax processing and computations of tax payment liabilities among others.

\section{Recommendations}

In view of this research study, the following recommendations are hereby made.

1. Government should equip the nation's tax offices and agencies with adequate ICT tools and facilities for better performance of tax related matters.

2. Tax administrators, tax agents and the employees in the ministry of Federal Board of Internal Revenue and the nations State Board of Internal Revenue should be regularly trained and retrained on the use of ICT tools and its facilities to enhance efficient service delivery.

3. Seminars and workshops should occasionally be organised to acquaint the staff, tax administrators and the relevant tax agencies on the practical use and applications of ICT tools and facilities.

\section{References}

[1]. Joe V. and Christoph S. (2010). Information Systems Today. New Jersey: Pearson Education Inc. Publishing. pp. 34, 100, 102, 216, 218, 229, 231

[2]. Lekan S. and Sunday O. K., (2006). TAXATION Principles and Practice in Nigeria. Ibadan: Silicon Publishing Company. pp. 3,4,6,195, 514,543

[3]. Mandel, M. (2012). Economics-The Basics. New York: McGraw-Hill Irwin. pp. 211, 212
[4]. Obot O.U. (2009). Enhancing the SocioEconomicDevelopment of Developing Countries Through Information and Communication Technology (ICT). Proceedings of National Conference of Nigeria Computer Society, Vol. 20, pp. 206

[5]. Odogbo F.J.(2002). Fundamentals of Computer and Information Technology. Benin-City: Dayspring Publication. pp. 5

[6]. Okonta O.E., Ajani D., Owolabi A., Onwubuya S.K. Onochie C. (2013). Understanding Computers and Information Technology. Enugu: Chembus Communication Ventures pp.. 211, 213, 216,217

[7]. Oseni M. (2016). Sustenance of Tax Administration by Information and Communication and Technology in Nigeria Journal of Archives of Business Research 4(1). P. 54

[8]. Samuelson, P.A. and Nordhaus W.D. (2010). Economics New York: McGraw-Hill Irwin. p.312 